$$
\begin{array}{r}
\text { https://doi.org/10.52696/DLPA6521 } \\
\text { Reprints and permission: } \\
\text { The Malaysian English Language Teaching Association } \\
\text { Corresponding Author: } \\
\text { Ramesh Nair ramesh@uitm.edu.my }
\end{array}
$$

\title{
(Re)constructing Teacher Identity through the Contesting Narratives of ELT Associations
}

\author{
Ramesh Nair \\ Academy of Language Studies, \\ Universiti Teknologi MARA, Shah Alam, Malaysia
}

\begin{abstract}
Discussions in the mainstream media about the declining standard of English in Malaysia have focused on a variety of contributing factors, one of the more prominent being the quality of teaching. English language teachers have been central actors in these narratives and are often easy targets for assigning blame. Left uncontested, such narratives have the capacity to shape a damaging image of Malaysian English language teachers which can have lasting implications for the ELT profession in the country. Fortunately, alternative voices emerge to challenge narratives describing Malaysian English language teachers as inept and incompetent. In this paper, I examine such narratives as they are presented through multimodal texts published and circulated in the public domain by the Malaysian English Language Teaching Association. Drawing on the frameworks of Systemic-Functional Linguistics and visual grammar, I examine a series of posters disseminated through the association's social media platforms. The analysis unpacks the language and images used in the posters, and reveals an alternative discourse in which these teachers are presented as trained professionals with expertise in their field of ELT. The study highlights the important role of ELT associations in representing its members by challenging emerging discourses which threaten the reputation of the profession.
\end{abstract}

\section{KEYWORDS: ELT associations, Systemic-Functional Linguistics, multimodal texts, teacher identity}




\section{Introduction}

Despite some contesting views, it remains largely held in most parts of the world that English proficiency is an important tool for career success, and the presence of a workforce proficient in English can significantly impact the economic performance of nations (McCormick, 2017). For this reason, governments invest heavily in ensuring that its people are able to communicate effectively in English in addition to other languages which they may use more regularly for everyday communication.

English proficiency is particularly high in Malaysia's national education agenda. News reports and discussions about the declining standard of English have featured prominently in the country's mainstream media for decades now as everyone from parents to politicians continue to weigh in on the issue. The complaints have generally been that students leaving school are not as proficient as they need to be to meet the demands at the workplace and higher education (Ting, Marzuki, Chuah, Misieng \& Jerome, 2017). This is despite the fact that English is taught as a compulsory subject in Malaysian primary and secondary schools.

In more recent times, the launch of the Malaysian Education Blueprint 2013-2025 reignited public conversations yet again about the poor standard of English among Malaysian students. The blueprint proposed 11 shifts to guide the nation's education reform agenda, and one of those shifts deals specifically with language proficiency (Ministry of Education, 2013). Around the time the blueprint was published, English language teachers were asked to sit for a language proficiency test. Based on their performance in the test, it was announced by the then Minister of Education II that two thirds of Malaysia's English language teachers were incapable of teaching the subject and needed to attend courses to help them improve their proficiency in the language (The Star Online, September 11, 2013). This remark by the minister then led to intense discussions about the competence of English language teachers. An investigation of the emerging narratives in the mainstream media by Nair and Arshad (2018) revealed that Malaysian English language teachers were denigrated as they were described as inept and incompetent.

This paper is anchored to the contention that with any professional identity, the identity of teachers is discursively shaped through individual and collective voices (Olausson, 2017; Schrewe, Bates, Pratt, Ruitenberg \& McKellin, 2017). Studies on teacher identity, particularly English language teacher identity, are important because it impacts the professional development of language teachers, and by extension, also affects classroom instruction and students (Reeves, 2018). Several studies have focused on language teacher identity for this reason. Yazan (2018) examined the narratives of TESOL student teachers as they made use of a tool for learning through identity development. The practice was found to empower users as it encouraged the view of teachers as knowledge generators. In another study related to implications for language teacher education, Karimi and Mofidi (2019) examined the identity enactment of second language teachers and found a variety of variables which contributed to how teachers saw themselves. Among these variables were the negotiation of varying identities which confronted teachers in the wider community. Studies on language teacher identity have also focused on English language teachers who regard English as an additional language to their first language. Wolff and De Costa (2017) examined how such teachers negotiated emotional challenges as part of their professional identity development and argued that there was a need for new pedagogical models which considered the 
emotion-related challenges of English language teachers. Clearly, these studies assert the importance of teacher identity in shaping teacher professionalism and classroom practices. Despite this, few studies have focused on language teacher identity in the Malaysian context.

Discussions on language teacher identity have emerged in the context of broader themes such as the influences on and experiences of pre-service teachers (Macalister, 2017). In a study about English teacher professionalism in Malaysia, Loo (2018) examined the narratives of an English language teacher to illustrate how the teacher's experiences with students, colleagues and classroom practices collectively constructed a multi-faceted image of teacher professionalism. Similarly, in another study by Ahmad and Abd Samad (2018), the narratives of a teacher of young learners were examined to identify the various metaphors which were used to construct the image of an English teacher of young learners. The metaphorical expressions pointed to an identity of the teacher as a nurturer, knowledge provider and disciplinarian, which the researchers argued, was a necessary part of teacher reflective practices. These studies however examined identity construction as performed by the teachers themselves, and did not consider the shaping of teacher identity by external forces. One study which did this was by Nair and Arshad (2018), who examined the discursive construction of English language teachers in Malaysia's mainstream media. The study illustrated the power of external narratives which contributed to a less than desirable image of Malaysian English language teachers. However, the paper was limited by the fact that it did not consider contesting narratives in the public sphere which may serve to challenge the image presented by those possessing discursive power. In the present study, I address this gap by investigating the alternative narratives presented by the Malaysian English Language Teaching Association (MELTA) through its social media platforms. Specifically, I examine how an English language teaching association makes use of posters disseminated in the public sphere to offer contesting narratives which position Malaysian English language teachers in a positive light, thereby challenging existing narratives of the inept Malaysian English language teacher. The dissemination of posters through social media sites is not the same as reports and opinion editorials published in mainstream newspapers. However, both newspapers and social media sites target and eventually reach the public. In examining the dissemination of news via Facebook, Welbers and Opgenhaffen (2019) assert that the lines between newspapers and social media sites have blurred, with Facebook becoming an important resource for producers and consumers of news. Therefore, the analysis of the promotional posters developed and distributed by MELTA is discussed in relation to news reports about Malaysian English language teachers because both are accessible to the wider public.

As posters make up the sample for analysis, the present study draws on Systemic-Functional Linguistics and visual grammar to analyse how teachers are represented as participants, as well as within processes and circumstances in language and image. The metafunctional principle within Halliday's Systemic-Functional theory provides the means through which language and visuals can be examined to understand how they interact to create meaning. The theory is anchored to the premise that language and visuals are brought together from a wide set of available resources to create meaning (O'Halloran, 2008). Researchers examining multimodal texts are drawn to Halliday's Systemic-Functional Linguistics (SFL) because it provides a common framework for explaining how both language and visuals serve to construct ideational meaning and enact interpersonal relations (O'Halloran, 2008). SFL calls for an understanding of choices made in 
meaning-making from three interrelated metafunctions, namely the ideational, interpersonal, and textual.

Metafunctions are mapped to the grammar of language to explain the functions of language in the meaning-making process. The ideational function is realised through language used to communicate experience and logic. Beyond this, language is also used to enact interpersonal relations between interactants in a communicative act. Mediating the ideational and interpersonal is the textual metafunction which allows the ideational and interpersonal to meet and be represented through grammatical systems. Drawing on SFL, researchers of visual communication later argued that visuals too perform like language to construct meaning. Drawing parallelisms to SFL, Kress and Van Leeuwen (2006) posit the theory of visual grammar in which visual elements work to create representational and interactive meaning. The following table illustrates the parallel concepts in SFL and visual grammar which are tied to identity construction and power relations:

Table 1: Metafunctions of Language and Parallel Dimensions of Visual Grammar

\begin{tabular}{|c|c|}
\hline Metafunctions of Language & Dimensions of Visual Grammar \\
\hline Ideational & Representational \\
\hline $\begin{array}{l}\text { Representation of participant experiences and } \\
\text { their state of being as found in process types } \\
\text { reflected in clause structures. } \\
\text { The process types include material, mental, } \\
\text { verbal, behavioural, existential, and relational } \\
\text { which are marked by verbs. }\end{array}$ & $\begin{array}{l}\text { Representation of participant experiences as } \\
\text { presented in narrative process (with actors } \\
\text { and goals) and conceptual process } \\
\text { (participants are represented as ideas in } \\
\text { more stable terms such as in analytical or } \\
\text { symbolic processes). }\end{array}$ \\
\hline Interpersonal & Interactive \\
\hline $\begin{array}{l}\text { The enactment of interpersonal relations } \\
\text { between interactants in communication using } \\
\text { lexico-grammatical resources which in turn } \\
\text { describe social roles and power relations. }\end{array}$ & $\begin{array}{l}\text { The interaction between the producer of the } \\
\text { image and the recipient. Messages are } \\
\text { encoded by the producer through gaze, } \\
\text { social distance represented through fields of } \\
\text { vision, power relations represented through } \\
\text { the angle of the gaze. }\end{array}$ \\
\hline Textual & Compositional \\
\hline $\begin{array}{l}\text { The realisation of the ideational and } \\
\text { interpersonal through an organized medium } \\
\text { of communication. }\end{array}$ & $\begin{array}{l}\text { The realisation of a text as it is organized } \\
\text { through resources such as the layout, } \\
\text { positioning, and salience of images }\end{array}$ \\
\hline
\end{tabular}

(Source: Ly \& Jung, 2015; Shin, Cimasko \& Yi, 2020) 


\section{Method}

The sites for the study are the social media platforms (namely, Facebook and Instagram) of the Malaysian English Language Teaching Association (MELTA). Established in 1958, MELTA is the oldest, and remains the only, national ELT association in Malaysia. Its 2020 annual report indicates membership at over 1000 life and ordinary members.

A review of its social media platform shows that the association actively engages with its followers and keeps its members informed of all upcoming activities. The association's Facebook account has over 7000 followers. A summary of its Facebook engagement report between 11 November 2020 and 11 December 2020 for example revealed that the association posted a total of 14 announcements within a one-month timeframe. Of the 14 announcements, 7 were announcements of upcoming MELTA activities, 2 were announcements of upcoming English language teaching and learning activities organised by other associations, 1 was a greeting for an upcoming festival, and 4 were announcements providing access to reports and recordings of past activities.

All upcoming activities were promoted with posters created to inform members and the wider community of English language teachers. All posters published by MELTA between the months of May and December 2020 were downloaded from the association's Facebook page. Next, posters which featured Malaysian English language teachers by naming them and/or presenting an image of them were isolated. Other posters such as festive greetings were eliminated.

The posters disseminated through MELTA's Facebook and Instagram accounts make up the sample for analysis because it is established that non-profit organisations rely a great deal on social media platforms for direct communication and engagement with stakeholders (Del Giudice, Maggioni, Rathi, Given, \& Forcier, 2014; Leong, Pan, Ractham, \& Kaewkitipong, 2015; Lober \& Flowers, 2011; Pang, Hassan, \& Chong, 2014), as well as to promote their activities (Waters, Burnett, Lamm, \& Lucas, 2009).

A total of 11 posters published and disseminated by MELTA between 1 May to 31 December 2020 make up the sample for the present study (refer to Appendix A for the posters).

The posters were examined to investigate the representation of Malaysian English language teachers through language and visuals by drawing on the frameworks of SFL and visual grammar (Ly \& Jung, 2015; Shin, Cimasko \& Yi, 2020). A broader definition of English language teachers is applied in the present study to include academics in higher learning institutions as well as education department personnel such as School Improvement Coaches tasked with supporting the teaching and learning of English at schools. This is because they all appear in the posters and represent educators responsible for enhancing the quality of English language education in Malaysia.

\section{Findings and Discussion}

All eleven events which ran over eight months prominently featured English language teachers from Malaysian schools, education departments and higher learning institutions. This in itself 
reflects MELTA's determination in showcasing the capacity of Malaysian educators in the field of English language teaching. All posters promoted online webinars which the association organised to promote continuing professional development among English language teachers during the COVID-19 pandemic. For this reason, most poster titles reflect the main focus of teachers at the time which was about managing the challenges related to the closing of schools and online instruction:

Table 2. Poster Titles and Description

\begin{tabular}{|c|c|c|}
\hline Code & Webinar Title & Description \\
\hline P1 & $\begin{array}{l}\text { Rising to the challenge: Teaching } \\
\text { and learning during the } \mathrm{MCO}\end{array}$ & $\begin{array}{l}\text { Teacher experiences with online teaching } \\
\text { A webinar describing the experiences of } \\
\text { English language teachers during the } \\
\text { Movement Control Order imposed in Malaysia }\end{array}$ \\
\hline $\mathrm{P} 2$ & $\begin{array}{l}\text { Part 1: Let's GoFormative! Using } \\
\text { a digital formative assessment } \\
\text { tool to get real-time feedback } \\
\text { Part 2: YouTube: So simple yet } \\
\text { so engaging }\end{array}$ & $\begin{array}{l}\text { Technology for teaching and assessment } \\
\text { A webinar on the use of technology in the } \\
\text { classroom presented by an academic from a } \\
\text { public university and an officer attached to a } \\
\text { district education office }\end{array}$ \\
\hline P3 & $\begin{array}{l}\text { Bringing TEDEd into your } \\
\text { classroom with Magdeline Muuk }\end{array}$ & $\begin{array}{l}\text { Conducting video-based lessons } \\
\text { A webinar by a secondary teacher who talks } \\
\text { about ways to feature TEDEd in the English } \\
\text { language classroom }\end{array}$ \\
\hline $\mathrm{P} 4$ & $\begin{array}{l}\text { Creative use of WhatsApp for } \\
\text { online teaching }\end{array}$ & $\begin{array}{l}\text { Technology for teaching and learning } \\
\text { A webinar on creative ways of using Whatsapp } \\
\text { for online English language classes by a school } \\
\text { improvement coach, with the session } \\
\text { moderated by a teacher }\end{array}$ \\
\hline P5 & $\begin{array}{l}\text { Highly immersive programmes } \\
\text { Post-COVID 19: Practicality in } \\
\text { limited space }\end{array}$ & $\begin{array}{l}\text { Teacher experiences with promoting the use } \\
\text { of English beyond regular lessons } \\
\text { A webinar by primary and secondary school } \\
\text { teachers and an academic on the }\end{array}$ \\
\hline
\end{tabular}




\begin{tabular}{|c|c|c|}
\hline & & $\begin{array}{l}\text { implementation of the Highly Immersive } \\
\text { Programme* }\end{array}$ \\
\hline P6 & $\begin{array}{l}\text { Facilitating active participation } \\
\text { through instructional strategies }\end{array}$ & $\begin{array}{l}\text { Encouraging active participation in } \\
\text { classrooms } \\
\text { A webinar moderated by a school teacher on } \\
\text { facilitating active student participation through } \\
\text { instructional strategies }\end{array}$ \\
\hline P7 & $\begin{array}{l}\text { Online webinar: From bricks to } \\
\text { clicks }\end{array}$ & $\begin{array}{l}\text { Technology for teaching and learning } \\
\text { A webinar on the use of technology for online } \\
\text { English language teaching by academics and a } \\
\text { school teacher }\end{array}$ \\
\hline P8 & $\begin{array}{l}\text { Action research: No research } \\
\text { without action, no action without } \\
\text { research }\end{array}$ & $\begin{array}{l}\text { Encouraging teachers to embrace research } \\
\text { A webinar on action research by a teacher } \\
\text { trainer }\end{array}$ \\
\hline P9 & $\begin{array}{l}\text { Flipping } \\
\text { assessment, and collaboration } \\
\text { with Flipgrid! }\end{array}$ & $\begin{array}{l}\text { Technology for teaching and learning } \\
\text { A webinar on engaging students in an online } \\
\text { speaking lesson by an academic from a public } \\
\text { university, moderated by a school teacher }\end{array}$ \\
\hline P10 & $\begin{array}{l}\text { Humanising ELT classrooms: A } \\
\text { heart to heart moment }\end{array}$ & $\begin{array}{l}\text { Teacher experiences with teaching English } \\
\text { in rural communities } \\
\text { A webinar on successes in the language } \\
\text { classroom featuring a Malaysian school } \\
\text { teacher who received global recognition in an } \\
\text { international event }\end{array}$ \\
\hline P11 & $\begin{array}{l}\text { Real talk, real teachers: Our } \\
\text { nogori champions! }\end{array}$ & $\begin{array}{l}\text { Teacher experiences with online teaching } \\
\text { A webinar featuring teachers who won } \\
\text { recognition awards for their work in the Highly } \\
\text { Immersive Programme*, an initiative by the } \\
\text { Ministry of Education Malaysia to promote } \\
\text { English in schools. }\end{array}$ \\
\hline
\end{tabular}

*The Highly Immersive Programme (HIP) is a Ministry of Education initiative to promote an environment where English is used beyond the confines of English Language classrooms, within school and through outreach activities (Pillai \& Ong, 2018). 
Within this set of titles, several were made up of -ing initiated non-finite clauses (P1, P2, P3, P6, P9, P10). The processes of "rising", "using", "bringing", "facilitating", "flipping", and "humanising" all have the teacher(s) as the understated actor in the clause structures. The teachers are therefore accorded the power to act, that is, to rise to the challenges (P1), to use a digital formative assessment tool (P2), to bring TEDEd into the classroom (P3), to facilitate active participation (P6), to flip engagement, assessment, and collaboration (P9), and to humanise ELT classrooms (P10). These titles serve an ideational function, creating a reality where teachers are decision makers, possessing the capacity to carry out a variety of tasks expected of them within the teaching profession.

In P3, the name of the presenter is worked into the title, "Bringing TEDEd into your classroom with Magdeline Muuk". This appears to elevate the teacher presenter to a celebrity as the title resembles names of television talk shows with popular hosts such as The Late Show with Stephen Colbert, The Tonight Show with Jimmy Fallon or Late Night with Seth Meyers.

The titles also serve an interpersonal function which establishes personal relations between the teacher association in its capacity as event organiser as well as the speaker(s) and the participating teachers. This is achieved through lexical-grammatical choices. For example, the use of the firstperson plural in P2, "Let's GoFormative", and P10, "Our nogori champions", serve to close ranks with a wider audience. However, it is also interesting to note that the use of such pronouns in imperative structures is also associated with establishing a divide. Kacewicz et al. (2014), cited in Markowitz and Slovic (2020) concluded in their study that those of high status (in this case, the ELT association) use the first-person plural when communicating with masses of lower status (in this case, the teacher participants). Therefore, although there is an attempt to narrow the psychological distance, power differences are reinforced.

Besides the use of pronouns, phrases like "heart to heart" (P10) create intimacy by appealing to the emotion of the audience while the colloquial use of "nogori" (P11) (meaning "state" in colloquial Negeri Sembilan Malay, a language spoken by the community in the state of Negeri Sembilan) personalises the communication with English language teachers in Malaysia as the deictic expression can only be completely understood through shared experiences (Reyes, 2015).

In other posters such as P4, P6, and P10, the background of the teacher presenter is described in some detail:

\section{P4}

Daphne Rosaline Henry Thomas has 28 years of teaching experience in both primary and secondary schools in the states of Pahang, Perak, Kuala Lumpur and Melaka in Malaysia. She is currently a School Improvement Specialist Coach (SISC+) in the Melaka Tengah District Education Office for the past 6 years. She holds a B.Ed (Hons) and a Masters in Linguistics. Her areas of interest are linguistics, teaching of English language, and the use of technology to teach language. (Sic). 
Farini bt Ahmad Fadil is currently a teacher at SMK Dato' Abdul Rahman Yaakub, Bota Kanan, Perak. She has taught for 19 years.

\section{P10}

Samuel Isaiah is one of the 10 finalists for Global Teacher Prize 2020. Join us and listen to his story in bringing about changes to his Orang Asli students through education. (Sic).

In P4, P6 and P10, attention is drawn to the credibility of the speakers and moderators of the events. In all three, their profession as teachers is foregrounded. References are made to their years of teaching experience ( $\mathrm{P} 4$ and $\mathrm{P} 6$ ), and initiatives to bring change through their role as teachers (P10). The biodata in the posters serve to extend the text, and while they originate from the individuals being described, the publication of the poster by the association suggests that it is an editorial choice made to assure would-be participants about the quality of the event (Mwinlaaru, 2017). The biodata therefore serves to position teachers as experts, much like researchers who have their biodata included in their published papers.

In addition to language, the visual representation of the teacher presenters in the posters also serves to convey authority and power. As a semiotic resource, visuals in multimodal texts serve to reinforce the written message or complement it. The images of the event speakers and moderators are presented as conceptual processes where they pose for viewers rather than be seen doing something (Ly \& Jung, 2015). In all but one of the 33 images of speakers and session moderators, the gaze is direct, demanding viewer engagement. The smile, again evident in all but one of the 33 images, serves to establish an affinity with the viewers. Furthermore, the portrait images with only the head and shoulders visible, serve to establish intimate relations while the image of the main speaker in P9 showing her from head to waist establishes personal relations with viewers (Ly \& Jung, 2015).

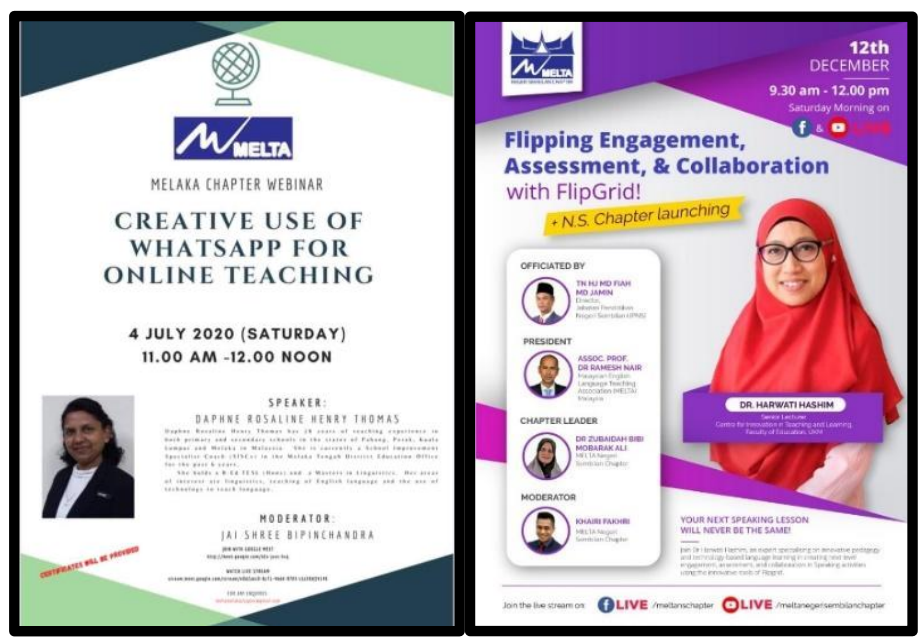

Figure 1.0. Comparison of Intimacy Levels between Head and Shoulder Images and Head to Waist Images

In P10, the single image of the teacher presenter is prominently positioned in the middle of the poster, centring attention on him in relation to general and concrete information placed as the ideal and the real at the top and bottom of the poster (Shin, Cimasko \& Yi, 2020). Although images of 
pupils appear at the top of the poster, they fade into the background as a translucent film covers the image and words across their faces makes them unidentifiable.

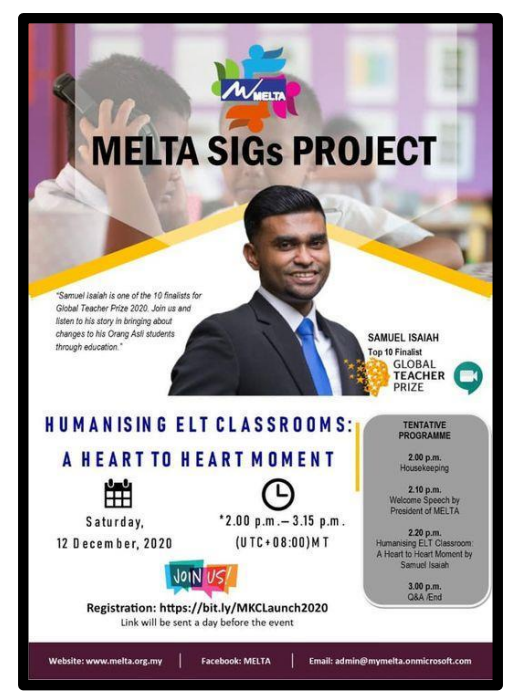

Figure 2.0. Establishing prominence through centring an image

The visual focus on Samuel Isaiah (P10) is further justified through language as he is described in a brief phrase as a finalist for the Global Teacher Prize, an award given by the Varkey Foundation to recognise an exceptional teacher who has made significant contributions to the teaching profession (see https://www.globalteacherprize.org/ for details). In other posters (P3, P4, and P8), the singular image of the teacher presenters also serves a similar purpose, which is to draw the eye of viewers to them and make them the focus of the event.

\section{Conclusion}

Texts represent and construct reality within a certain ideological system, and left uncontested, these texts can serve to centre power and privileges in the hands of a dominant few (De los Heros, 2009). Narratives in Malaysia, as shaped by political elites and the mainstream media, have to some extent delegitimised the authority of English language teachers in the country (Nair \& Arshad, 2018). In this paper, I have attempted to show how alternative narratives circulated by a national ELT association contest the disparaging image of the inept Malaysian English language teacher. The creation and circulation of posters by MELTA for promoting continuing professional development activities also position Malaysian English language teachers as experienced professionals possessing the expertise to address the inherent challenges of teaching English. These contesting narratives have implications for the English language teaching landscape in Malaysia. In many parts of the world, Non-Native English-Speaking Teachers (NNESTs) are perceived as lesser than Native English-Speaking Teachers (NEST) in terms of their language skills and pedagogical knowledge (Floris and Renandya, 2020), and the mainstream narratives of inept or incompetent Malaysian English language teachers certainly feeds the same discriminatory assertions. It is not unusual to hear of schools and language centres which choose to employ individuals who fit the universal image of a NEST over NNESTs who may actually possess higher professional qualifications and more experience. Discriminatory practices are also observed in Malaysia where the absence of a formal description of Malaysian English results in Malaysian 
English language learners and teachers being judged against unattainable native speaker norms (Pillai \& Ong, 2018).

Floris and Renandya (2020) opine that ELT associations have a role in challenging nativespeakerism and empowering trained and qualified NNESTs through professional development programme. The activities promoted through the posters which were analysed in this study were certainly geared towards providing continuing professional development opportunities. However, beyond that, the content of the posters also serves to empower the community of NNESTs by presenting Malaysian English language teachers as authorities in various areas related to ELT.

The findings presented in this paper are however limited by the small number of posters which were analysed. This is a consideration for future studies on teacher identity which draw on multimodal texts. There is a need to understand how teachers themselves shape their professional identity, and this is particularly important in the context of Malaysian English language teachers. Researchers should turn their attention to social media sites to examine how teachers assert their agency through personal narratives or dialogic communication on topics related to their professional identity.

\section{References}

Ahmad, N. K., \& Abd Samad, A. (2018). Metaphors as proxies for identity: A case study of teaching English to young learners (TEYL) teacher. 3L: Language, Linguistics, Literature, 24(4), 143-157.

De los Heros, S. (2009). Linguistic pluralism or prescriptivism? A CDA of language ideologies in Talento, Peru's official textbook for the first-year of high school. Linguistics and Education, 20(2), 172-199.

Del Giudice, M., Maggioni, V., Rathi, D., Given, L. M., \& Forcier, E. (2014). Interorganisational partnerships and knowledge sharing: the perspective of non-profit organisations (NPOs). Journal of Knowledge Management, 18(5), 867-885.

Floris, F. D., \& Renandya, W. A. (2020). Promoting the Value of Non-Native English-Speaking Teachers. PASAA: Journal of Language Teaching and Learning in Thailand, 59, 1-19.

Karimi, M. N., \& Mofidi, M. (2019). L2 teacher identity development: An activity theoretic perspective. System, 81, 122-134.

Kress, G., \& Van Leeuwen, T. (2002). Colour as a semiotic mode: notes for a grammar of colour. Visual communication, 1(3), 343-368.

Leong, C. M. L., Pan, S. L., Ractham, P., \& Kaewkitipong, L. (2015). ICT-enabled community empowerment in crisis response: Social media in Thailand flooding 2011. Journal of the Association for Information Systems, 16(3), 174-212.

Loo, D. B. (2018). Examining English Teacher Professionalism through Dialogic Narrative Inquiry: A Case from Sabah, Malaysia. 3L: Language, Linguistics, Literature, 24(4), 171184.

Lindahl, K., \& Yazan, B. (2019). An identity-oriented lens to TESOL teachers' lives: Introducing the special issue. TESOL Journal, 10(4), 1-5.

Lober, W. B., \& Flowers, J. L. (2011, August). Consumer empowerment in health care amid the internet and social media. Seminars in Oncology Nursing, 27(3), 169-182.

Ly, T. H., \& Jung, C. K. (2015). Multimodal discourse: A visual design analysis of two advertising images. International Journal of Contents, 11(2), 50-56.

Macalister, J. (2017). English and language teacher education in Malaysia: An exploration of the influences on and experiences of pre-service teachers. RELC Journal, 48(1), 53-66. 
Markowitz, D.M., \& Slovic, P. (2020) Communicating Imperatives Requires Psychological Closeness But Creates Psychological Distance. Journal of Language and Social Psychology, 39(5-6), 598-625. https://doi.org/10.1177/0261927X20902816

McCormick, J. (2017). Understanding the European Union: a concise introduction. Palgrave.

Ministry of Education (2013), Malaysia Education Blueprint, Ministry of Education, Putrajaya.

Montgomery, M., \& Feng, D. (2016). 'Coming up next': The discourse of television news headlines. Discourse \& Communication, 10(5), 500-520.

Mwinlaaru, I. N. I. (2017). Bridging boundaries across genre traditions: A Systemic Functional account of generic patterns in biodata. Functions of Language, 24(3), 259-293

Nair, R., \& Arshad, R. (2018). The discursive construction of teachers and implications for continuing professional development. Indonesian Journal of Applied Linguistics, 8(1), 131138.

O'Halloran, K. L. (2008). Systemic functional-multimodal discourse analysis (SF-MDA): Constructing ideational meaning using language and visual imagery. Visual communication, 7(4), 443-475.

Olausson, U. (2017). The reinvented journalist: The discursive construction of professional identity on Twitter. Digital Journalism, 5(1), 61-81.

Pang, A., Hassan, N. B. B. A., \& Chong, A. C. Y. (2014). Negotiating crisis in the social media environment: Evolution of crises online, gaining credibility offline. Corporate Communications: An International Journal, 19(1), 96-118.

Pillai, S., \& Ong, L. T. (2018). English (es) in Malaysia. Asian Englishes, 20(2), 147-157.

Reeves, J. (2018). Teacher identity. The TESOL Encyclopedia of English language teaching, 1-7. https://doi.org/10.1002/9781118784235.eelt0268

Reyes, A. (2015). Building intimacy through linguistic choices, text structure and voices in political discourse. Language \& Communication, 43, 58-71.

Schrewe, B., Bates, J., Pratt, D., Ruitenberg, C. W., \& McKellin, W. H. (2017). The Big D (eal): professional identity through discursive constructions of 'patient'. Medical Education, 51(6), 656-668.

Shin, D. S., Cimasko, T., \& Yi, Y. (2020). Development of metalanguage for multimodal composing: A case study of an L2 writer's design of multimedia texts. Journal of Second Language Writing, 47 (February), 1-14

Ting, S. H., Marzuki, E., Chuah, K. M., Misieng, J., \& Jerome, C. (2017). Employers'views on importance of English proficiency and communication skill for employability in Malaysia. Indonesian Journal of Applied Linguistics, 7(2), 315-327.

The Star Online, September 11, 2013. https://www.thestar.com.my/news/nation/2013/09/11/idris-many-teachers-not-fit-to-teach70-of-english-instructors-found-to-be-incapable-says-education/

Waters, R. D., Burnett, E., Lamm, A., \& Lucas, J. (2009). Engaging stakeholders through social networking: How nonprofit organizations are using Facebook. Public Relations Review, 35(2), 102-106.

Welbers, K., \& Opgenhaffen, M. (2019). Presenting news on social media: Media logic in the communication style of newspapers on Facebook. Digital Journalism, 7(1), 45-62.

Wolff, D., \& De Costa, P. I. (2017). Expanding the language teacher identity landscape: An investigation of the emotions and strategies of a NNEST. The Modern Language Journal, 101-S, 76-90.

Yazan, B. (2019). Toward identity-oriented teacher education: Critical autoethnographic narrative. TESOL Journal, 10(1), 1-15. 